\title{
ESTIMATION OF CEPHALOSPORINS (CEFTRIAXONE, CEFTAZIDIME) ANTIBIOTICS AS PURE AND PHARMACEUTIC FORMS BY COLOR PRODUCED REACTION IN UV-VIS SPECTROPHOTOMETIC TECHNIQUE
}

\author{
${ }^{1 *}$ Mohauman Mohammad Majeed AL-Rufaie, ${ }^{2}$ Zahraa Yosif Motaweq \\ ${ }^{1}$ Chemistry Department, College of Science, Kufa University \\ Iraq \\ ${ }^{2}$ Biology Department, College of Science, Kufa University \\ Iraq \\ *Corresponding author, email: muhaimin.alrufaie@uokufa.edu.iq \\ Co-author, email: zahraayosif@uokufa.edu.iq
}

\begin{abstract}
A new simple, accurate and low cost-effective UV-VIS spectrophotometric methods has been developed for the analysis of chosen cephalosporins (ceftriaxone, ceftazidime) in bulk samples and pharmaceutical dosage forms by using a specific color-generated reaction. This method involves the Schiff 's base formation reaction between selected cephalosporins with alcoholic 5-sulfo salicylaldehyde reagent 5SSA with heating to establish a yellow colored product displaying $\lambda$ max at $426 \mathrm{~nm}$ as well as $412 \mathrm{~nm}$ sequentially. These methods applied to the Beer's law through the range of concentration was $\left(4-60 \mu \mathrm{g} . \mathrm{ml}^{-1}\right)$, (5 -50 $\left.\mathrm{g} \mathrm{ml}^{-1}\right)$ respectively for two drugs. The analysis results for these studies have been tested statistically by the studies of recovery. These methods were successfully applied to the determination of the cephalosporins in bulk form and in Pharmaceuticals additionally it was shown that these methods have equivalent accuracy with the common method(BP)estimation procedures for the studied drugs. The interferences from frequently taken excipients were no influence on the estimation process. The study could discover a good as an employment cost-influence and speed method which that possibility used for making quality control for these cephalosporin antibiotics.
\end{abstract}

Keywords: UV-VIS Spectrophotometric, Cephalosporins, Pharmaceutics, Ceftriaxone and Ceftazidime

\section{INTRODUCTION}

Cephalosporins medicines are one type from b-lactam antibiotics appeared in the 1950 's as well as they are made by different species of the matrix cephalosporium additionally they are taken from semi-synthetic approaches [1]. Cephalosporins are wide antibiotics spectrum, through the strong effectiveness of various bacteria (broad spectrum). These are bacteria highly averse to deactivation through b-lactamases, extremely those made by bacteria (broad spectrum). They besides have comparatively little serum protein 
connecting potentially as well as nearly each one are evacuated during the nephritic route [2]. These medicines are ordinarily utilized in the dealing with urinary tract as well as upper respiratory infections. These medicines besides ordinarily utilitarian for the scarce sick person who is reactive penicillin even if sensitiveness to cephalosporin medicines is besides as some point discover $[3,4]$. The essential nucleus of the cephalosporins is (7-ACA)7amino-cephalosporanic acid,that be composed a di-hydro thiazine nucleus into a $\beta$-lactam ring. These medicines are conventional separated(1-2-3 and 4 initiation performers, depended forcefully on their time realization as well as their antimicrobial characterizes i.e. spectrum activeness [5,6] Ceftriaxone $(\mathrm{M} . \mathrm{wt}=662)$ was a third- initiation cephalosporin antibiotic. Chemically Ceftriaxone ceft is (6R,7R,Z)-7-(2-(2-amino thiazol-4-yl)-2-(methoxy imino) acetamido)-3-((6-hydroxy-2-methyl -5-oxo - 2,5- dihydro -1,2,4-triazine-3-ylthio)methyl)-8oxo-5-thia-1-aza-bicyclo[4.2.0]oct-2-ene-2-carboxylic acid [7]. Like other third- initiation cephalosporins, it has broad spectrum activity against Gram-positive and Gram-negative bacteria [8]. Ceftazidime (M.wt = 637) penta hydrate $\mathrm{cfz}$ is $(\mathrm{Z})-(7 \mathrm{R})-7-[2-(2-$ amino thiazol4-yl)-2-(1- carboxy-1- methoxy imino) acetamido]-3-(1-pyridiniomethyl)-3-cephem-4carboxylate penta hydrate. thecfz is a third generation of cephalosporin antibiotic represented through a wide broad spectrum antibiotic additionally averse to b-lactamase making by bacteria in addition to its antimicrobial activeness opposition, Staphylococci, Pneumococci additionally Streptococci $[9,10]$. The chemical structures of (Ceftriaxone are $\mathrm{C}_{18} \mathrm{H}_{16} \mathrm{~N}_{8} \mathrm{Na}_{2} \mathrm{O}_{7} \mathrm{~S}_{3}, 3 \frac{1}{2} \mathrm{H}_{2} \mathrm{O}$, as well s Ceftazidime $\mathrm{C}_{22} \mathrm{H}_{22} \mathrm{~N}_{6} \mathrm{O}_{7} \mathrm{~S}_{2}, 5 \mathrm{H}_{2} \mathrm{O}$ ) Figure (1).

Chemical properties of ceft is freely soluble in water, sparingly soluble in methanol, very slightly soluble in anhydrous ethanol, cfz, white or nearly white, fine crystal clear, a little soluble in methyl alcohol as well as water, virtually insoluble ethyl alcohol additionally in acetone. It disperses in alkali as well as acidic solutions. The common approaches for the cephalosporins analysis were HPLC proficiencies in the back phase manner $[11,12]$. Diverse additional replacement approaches have been recorded for the analyzes of the cephalosporins, The approaches were contained spectrophotometric[1, 2, 13], spectrofluorometric [14-16], chemiluminescence [17-19], chromatographic[20-23], and electrochemical methods [24-27]. This paper reports a study on the development of new validated UV-spectrophotometric methods for the quantitative determination of Cephalosporins:Ceftriaxone and Ceftazidime as bulk and solid dosage form. By a specific color-generated reaction. This method involves the $\mathrm{t}$ Schiff 's base formation reaction between 
selected cephalosporins with alcoholic 5-sulfo salicylaldehyde reagent (5SSA) with heating to form yellow colored chromogens with high accuracy and precision.

\section{MATERIAL AND METHOD}

\section{Materials and reagents}

Everyone of spectra as well as absorbance appreciations was made through applied a UVVisible double-beam (160 digital) reporting spectrometer (Japan). Cooling-Heating water bath (Haake, Fe3), sensitive balance (Sartorius BL 210S). The chemicals which were used in the approach with high degree of purity and did not need to purification, all reagents in the research was given from $(\mathrm{BDH})$ (reagent Laboratory,Chemicals Ltd), their solutions were prepared by the following:

Ceftriaxone sodium drug: 500 ppm standard concentration solution of ceft was prepared by dissolution $0.05 \mathrm{~g}$ of ceft in $100 \mathrm{ml}$ with deionized water in a volumetric flask.

Ceftazidime pentahydrate drug: $500 \mathrm{ppm}$ standard concentration solution of $\mathrm{cfz}$ was prepared by dissolution $0.05 \mathrm{~g}$ of $\mathrm{cfz}$ in $100 \mathrm{ml}$ with deionized water in a volumetric flask.and heating for $20 \mathrm{~min}$ to complete the dissolution of cfz drug in water. The drug solutions were transferred to a dark flask and it is stable for at least one week the solution was stayed stable for more of one month after keeping away from the light.the working solution prepared from this solution.

An alcoholic solution of 5-sulfo salicylaldehyde reagent (5SSA) $0.04 \mathrm{M}$ :was prepared by dissolving $2.02 \mathrm{gm}$ from reagent in $25 \mathrm{ml}$ of ethanol absolute in the volumetric flasks.

\section{General procedure [28]}

Aliquots of $(0.2 \mathrm{ml}-4.0 \mathrm{ml})$ ceft as well as $\mathrm{cfz}$ were transported into a sequence of volumetric flasks $25 \mathrm{ml}$. To each flask, alcoholic solution $2.0 \mathrm{ml}$ for 5-sulfo salicylaldehyde was utilized as well as warmed at $70{ }^{\circ} \mathrm{C}$ for 50 minfor ceft and $60 \mathrm{~min}$ ) for cfz. The volumes were as weakened to the mark with ethyl alcohol additionally the yellow colored agents absorbance was checked at $426 \mathrm{~nm}$ as well as $412 \mathrm{~nm}$ averse to the blank agent solution.The colored agents were as stable for high than 1 hour. The ceft as well as cfz quantities are examined was checked from the calibration curve. The colors were was discovered that be stable for more from 2 days. 
Assay procedure for Ceftriaxone sodium and Ceftazidime sodium in Pharmaceutical preparations: A number of preparations containing ceft and cfz as ingredient active were analyzed. These are summarized in Table 1 and 2.

\section{Injection vial preperation:}

$0.05 \% \mathrm{gm} / \mathrm{ml}$ from the powder of each type of vials which was containing ceft and cfz as ingredient active was taken into $100 \mathrm{ml}$ flasks volumetric and weakened up to the imprint with ethanol solvent.At that point,we computed the concentration by using the calibration curve [11].

\section{RESULT AND DISCUSSION}

Various circumstances were contemplated that are influencing on the absorbance for the resulant compound that leads to increase it.

\section{Effect of (5SSA) reagent Concentration}

The study the reagent effect of 5SSA on the absorbance .It was making by utilizing $1 \mathrm{ml}$ of $500 \mathrm{ppm}$ from ceft and cfz drugs were transferred into a sequence of $25 \mathrm{ml}$ volumetric flasks, varying volumes for 5SSA $0.04 \mathrm{M}$ from $0.5-8 \mathrm{ml}$ was taking from alcoholic solution of 5-sulfo salicylaldehyde was taken and warmed at $70{ }^{\circ} \mathrm{C}$ for 50 minutes for ceft and 60 minutes of $\mathrm{cfz}$, for the formation the Schiff base and complete the volumes by utilizing ethanol,the final volume was $2 \mathrm{ml}$ for the reagent of both drugs, that volumes produce the large absorption, that was utilized in the next experiments [29] .

\section{Effect of heating}

The heating effect was checked for the range wide of temperature from $(20-120)^{\circ} \mathrm{C}$. It was found the color activity expanded with warming up to $25^{\circ} \mathrm{C}$, and it was slightly increased at higher temperatures. The highest absorbance was at $70{ }^{\circ} \mathrm{C}$ for 50 minutes for ceft and 60 minutes of cfz,the next experiments were performed at this temperature that need to Schiff bases formation to simplify the analytical procedure [30].

\section{Effect of the time for completing the Schiff base reaction}

After heating and mixing well in $70{ }^{\circ} \mathrm{C}$ boiling water bath at room temperature for drug and reagent It was found 50 minutes for ceft and 60 minutes of cfz that the best times for completing the Schiff base reaction which selected in subsequent experiments. The resulted color products were as stabilized at over than 24 hour [28]. 


\section{Absorption Spectra}

The spectral scan was directed to get the more absorption wavelength of coming about the Schiff base compounds that result from two drugs subsequent to introducing the perfect circumstances for this reactions.a gainst blank solution ethanol solvent $98 \%$, after that,the spectral scan was obtained the greater wavelength absorption for the colour complexes which was resulted from the reaction between the drugs and the reagent.

\section{Quantification :}

Appling the perfect circumstances was showing by the procedure, a calibration curves linear for ceft drug and cfz drug is showed in figure 3, from this curve the Beer's law is applied between the range of concentrations of $(4-60 \mu \mathrm{g} / \mathrm{ml})(5-50 \mu \mathrm{g} / \mathrm{ml})$ for two drugs respectively, with ceft drug the correlation coefficient was 0.9992 , the slope of curve was 0.0301 , and an intercept of 0.0344 . The highly molar absorptivity of the yellow product was founding $\left(1.9926 \times 10^{4}\right) \mathrm{L} \cdot \mathrm{mol}^{-1} \cdot \mathrm{cm}^{-1}$. The sensitivity Sandal was $\left(4.5 \times 10^{-5}\right)\left(\mu \mathrm{g} . \mathrm{cm}^{-2}\right)$. The limit detection (LOD) was $1.121 \mu \mathrm{g} \cdot \mathrm{ml}^{-1}$ as well as the LOQ was $1.943 \mu \mathrm{g} \cdot \mathrm{ml}^{-1}$.and showing in table (3).

\section{Interferences}

The specificity of the suggested kinetic spectrophotometric procedures (fixed time procedure) for investigation of the ceft and cfz drugs within the sight of often experienced excipients like, talc, lactose, acacia, starch, glucose, sucrose, polyvinylpyrrolidone (PVP), magnesium stearate, and aspartate by the presented study. The solutions of studied drugs was framed and everyone from the studied excipients was given independently by ten-times concentrations more than of studied drugs were prepared by the self-procedure in the Calibration curve. 1 $\mathrm{ml}$ of 500ppm ceft, cfz solutions and $1 \mathrm{ml}$ of every excipients solutions was connected for the study of interferences after that dilution to the sign of volumetric flask $25 \mathrm{ml}$. A grade of impedance was believed to make the procedure more satisfactory if the mistake was not more than $\pm 2 \%$ in respect to the normal no obstructions were seen on the investigation of drugs within a sight of the studied excipients (Three determinations Average) [31] Table(4).

\section{The stoichiometry of reaction}

The stoichiometry of the reaction of two drugs ceft and cfz with 5SSA was performed by mole ratio method and Job's method. The methods applied by using the solution $1 \times 10^{-3} \mathrm{M}$ of every one of the medicines as well as the reagent to determine the colour products stoichiometry. The solutions absorbance were calculated at maximum wave lengths $426 \mathrm{~nm}$, $412 \mathrm{~nm}$ for to the color products. From these methods the results are showing that $1: 1$ new 
compound (Drug : 5SSA) compounds was formed at $426 \mathrm{~nm}, 412 \mathrm{~nm}$ alternately. The products formed was ethanol soluble. A reactions mechanism based on the above reactions is shown in Schemes figure (5 and 6) [24-26]. The stability constant for the product compounds was figured by looking and measuring the absorbance of a solutions which including stoichiometric measure of Drugs with 5SSA with the perfect quantity $1 \mathrm{ml}$ $2 \times 10^{-3} \mathrm{M}$ from medicines and 5SSA solution with other solution containing a five-fold excess from the starting concentration. The average for calculated stability constant for the colour results in ethanol under the characterized experimental circumstances was $3.11 \times 10^{5} 1^{2} \cdot \mathrm{mol}^{-2}$ for ceft drug and $1.26 \times 10^{5} 1^{2}$. $\mathrm{mol}^{-2}$ for cfz drug[32-34]. The interaction may be happened as obtained by the next Schemes Figure (6 and 7).

\section{Effect of solvent}

The type of solvent that was dissolving the drug substances employed affects both the wavelength and intensity of maximum absorption. Table (5) shows the effect solvent, ethanol was the best solvent, which gives very high intensity of maximum absorption which was in the case of using 5SSA as the aromatic aldehyde with two drugS. Ethanol is appeared to be a decent solvent from the point perspective of economy and sensitivity [29].

\section{Application of the procedure [35-37]}

The procedures was applied for the assay of pharmaceutical preparations of the two drug, was studied. The consequence of examining for accessible formulations of ceft and cfz drugs are appeared by following Table (6 and 7). Wherever the three normal determinations. also, the standard strategy was gotten from (2009) British Pharmacopeia. The outcomes were replicable and the determination procedures of formulations were through examined by the Standard procedure the studied approaches was felicitously utilized to estimate ceft and cfz as pure form and in its pharmaceuticals forms. The results given were checked statistical comparison by an $F$-test variance ratio for precision additionally for accuracy by utilizing Student's $t$-test with the common approach [5]. The results appeared that The values of the $F$ test and $t$-test. Were $(F=1.72, t=1.03)$ for ceft medicine and $(F=2.12, t=0.88)$ for $\mathrm{cfz}$ medicine, these values were little from the theoretical amount $(F=5.05, t=2$. 29) for ceft and ( $F=9.29, t=2.45)$ for $\mathrm{cfz}$ drug, pointing there was no clear distinction between the tested approaches and common approaches. Three estimations average ultimately, F-test as well as t-test values (statistical analysis) seem that there is no considerable variation in accuracy between the tested procedure additionally the common BP procedures. 


\section{CONCLUSION}

The present spectrophotometric procedures was a rapid, easily, sensitive and precise procedures has been created for the investigation of trace quantities of ceft and cfz drugs relevant for the investigation of two drugs in pure forms and injection samples. The proposed procedures are free from basic exploratory conditions and muddled systems, for example, extraction step. The reagents utilized as a part of the procedures are shabby, promptly accessible and the methods don't include any dreary sample preparation. These points of interest empower the utilization of the presented techniques in quality routine control investigation of ceft and cfz drugs in pharmaceutical preparations.

\section{REFERENCES}

[1] M. E. Abdel-Hamid: FSQ spectrophotometric and HPLC analysis of some cephalosporins in the presence of their alkali induced degradation products, Il Farmaco,1998;53 (2),132-138.

[2] O. A. Adegoke, and O. E. Umoh: A new approach to the spectrophotometric determination of metronidazole and tinidazole using p-dimethyl amino benzaldehydes, Acta Pharm., 2009;59(4), 407-419.

[3] J. N. Delgado and W.A. Remers: Wilson and Griswold's Textbook of Organic Medicinal and Pharmaceutical Chemistry, tenth ed. Lippincott Williams \& Wilkins, New York, 2004,653.

[4] C. Dollery: Therapeutic Drugs, vol. 1, third ed. Churchill Livingstone, Edinburgh, 1999,321.

[5] A. F. M. El-Walily, A. A. Gazy, S. F. Belal, and E. F. Khamis: Selective spectrofluorometric determination of phenolic b-lactam antibiotics through the formation of their coumarin derivatives, J. Pharm. Biomed. Anal., 1999, 20 (4), 643653.

[6] K. Kelani, L. I. Bebawy, and L. Abdel-Fattah:Stability-indicating spectrophotometric and densitometric methods for determination of some cephalosporins, J.AOAC Int., 1998, 81 (2), 386-393.

[7] G.H. Frederick: Penicillin, cephalosporin, and other - lactam antibiotics. Goodman and Gillman's. The pharmacological basis of therapeutics. 11th ed. New York: McGraw Hills Medical Publishing Division,2006,321.

[8] Gladwin and Mark :Clinical Microbiology Made Ridiculously Simple 4th ed.. Miami, FL: Med Master, Inc,2007, 67.

[9] J.F.Graumlich:Lactam antibiotics .Modern pharmacology with clinical applications. 6th edition. Philadelphia: Lippincott Williams \& Wilkins, 2003,554.

[10] Martindale-The Complete Drug Reference, 33rd ed., Pharmaceutical Press, London, 2002,174.

[11] The British Pharmacopoeia, Her Majesty's Stationary Office, London, 2009,1163,1169,8255.

[12] US Pharmacopoeia XXIIth Rev., US Pharmacopoeia Convention, 2009,329,521.

[13] F.A. Aly, M. M. Hefnawy, and F. Belal: A selective spectrofluorometric method for the determination of some a-amino cephalosporins in formulations and biological fluids, Anal. Lett., 1996,29 (1), 117-130. 
[14] D. Agbaba, S. Eric, K. Karljikovic-Rajic, S. Vladimirov, and D. ZivanovStakic: Spectrophotometric determination of certain cephalosporins using ferrihydroxamate method, Spectroscope. Lett., 1997,30 (2), 309-319.

[15] J.H. Yang, Q.L. Ma, X. Wu, L. M. Sun, and X.H. Cao:A new luminescence spectrometry for the determination of some balsamic antibiotics, Anal. Lett., 1999, 32 (3), 471-480.

[16] M. M. Hefnawy Y. El-Shabrawy, and F. Belal: Spectrofluorometric determination of alpha-amino cephalosporins in biological fluids and pharmaceutical preparations, $J$. Pharm. Biomed. Anal.,1999, 21 (4), 703-707.

[17] H. Yao, Y. Tang, Y. Li, and Y. Sun: Flow injection chemiluminescence determination of cephalosporin antibiotics by their enhancing effects on luminal-potassium periodate system, Anal. Lett.,2003 36 (14), 2975-2983.

[18] Y.Li and J. Lu: Chemiluminescence flow injection analysis of B lactam antibiotics using the luminal-permanganate reaction, Luminescence,2006, 21 (4), 251-255.

[19] C. Thongpoon, B. Liawruangrath, S. Liawruangrath, R.A. Wheatley, and A. Townshend: Flow injection chemiluminescence determination of cefadroxil using potassium permanganate and formaldehyde system, J. Pharm. Biomed. Anal., 2006,42 (2), 277-282.

[20] V.M. Shinde, and C.V. Shabadi, C.V: Simultaneous determination of cefadroxil and cefalexin from capsules by reversed phase HPLC, Indian Drugs, 1997,34, 399-402.

[21] V.M. Shinde, and C.V. Shabadi, C.V: Simultaneous determination of cephazolin and cefotaxime from injections by reversed phase HPLC, Indian J. Pharma. Sci.,1998, 60 (5), 313-315.

[22] G.Misztal: Determination of cefotaxime and cefotriaxone in pharmaceuticals by HPLC,Pharmazie, 1998,53,723-724.

[23] W.R. La Course and C.O. Dasenbrock: Pulsed electrochemical detection of sulfur containing antibiotics following high performance liquid chromatography, J. Pharm. Biomed. Anal., 1999,19 (1-2), 239-252.

[24] N. A. El-Maali, A. M. M. Ali, and M.A. Ghandour: Electrochemical reduction and oxidation of two cephalosporin antibiotics: ceftriaxone (rocephin) and cefoperazone (cefobid), Electro analysis (N.Y.),1993, 5 (7), 599-604.

[25] L. N. C. Rodrigues, M. B. V. Zanoni, and A. G. Fogg: Indirect polarographic and cathodic-stripping voltammetric determination of cefaclor as an alkaline degradation product, J. Pharm. Biomed. Anal.,1999, 21 (3), 497-505.

[26] V. S. Ferreira, M.V.B. Zanoni, and A.G. Fogg: Cathodic stripping voltammetric determination of ceftazidime with reactive accumulation at a poly-L-lysine modified hanging mercury drop electrode, Anal. Chim. Acta,1999, 384 (2), 159-166.

[27] S. A. Ozkan, N. Erk, B. Uslu, N, Yilmaz, and I. Biryol: Study on electro oxidation of cefadroxil monohydrate and its determination by differential pulse voltammetry, $J$. Pharm. Biomed. Anal.,2000, 23 (2-3), 263-273.

[28] K. R. Patel, V. D. Patel, K. P. Patel and V. G. Patel:Development and Validation of Spectrophotometric Method for Determination of Ceftriaxone Sodium in Pharmaceutical Dosage Forms, Der Pharma Chemica,2010,2(5),255-259.

[29] M. M. Al-Rufaie, A.N.Al-Sharefy, K.H.Kathem: a New spectrophotometric method for the determination chlorpromazine hydrochloride in pharmaceutical preparations by using oxidative coupling reaction. Inter. J. of Uni. Pharmacy and Bio Sciences, 2013,2(4), 184-189.

[30] M. M. Al-Rufaie: a New spectrophotometric method for the determination of Sulfamethoxazole drug, W.J.of pharmacy and pharmaceutical sciences,2016,5(3),172-180. 
[31] A. A. Jawad and K.H.Kathem: spectrophotometric determination of metoclopramide hydrochloride in bulk and pharmaceutical preparations by the diazotization-coupling reaction, Inter.J.of Pharmacy and Pharmaceutical Sciences,2013.5(3),294-298.

[32] F. M. A. Rind, M. G. H. Laghari, A. H. Memon, U.R. Mughal, F. Almani, N. Memon, M. Y. Khuhawar, and M. L. Maheshwari: Spectrophotometric Determination of Ceftriaxone Using 4-Dimethylaminobenzaldehyde, Pak.J.Anal. Environ. Chem.,2008,9(2),42-48.

[33] M. M. Al-Rufaie: Modern kinetic spectrophotometric procedure for estimation of furosemide drug as bulk form and in pharmaceuticals preparations, Curr. Issues Pharm. Med. Sci.2016,29(4),184-189.

[34] B. Hiremath, B.H. Mathada, and M. unjayaswam: Development and validation of spectrophotometric methods for determination of ceftazidime in pharmaceutical dosage forms, Acta Pharm.,2008,58, 275-285.

[35] M. I. H. Helaleh, E. S.M. Abu-Namch, and R. M. A. Q. Jamhour: Direct titration and indirect spectrophotometric determination of selected cephalosporins, Acta poloniae pharmaceutica,1998,55(2),93-97.

[36] A. A. Ramadan, H. Mandil, and M. Dahhan: UV-VIS Spectrophotometric study for determination of cefixime in pure form and in pharmaceuticals through complexation with $\mathrm{Cu}(\mathrm{II})$ using acetate- $\mathrm{NaOH}$ buffer in water: methanol, International $J$. of Pharmacy and Phar. Sci.,2013,5(1),428-433.

[37] A. J. Abdulghani, and S. K. Mohuee: Synthesis of gold nanoparticles using ceftriaxone sodium as a reducing and stabilizing agent, Iraqi Journal of Science,2015,56(3C),2425--2438. 
Table 1. Pharmaceutical preparation studied for Ceftriaxone sodium

\begin{tabular}{|c|c|c|}
\hline $\begin{array}{c}\text { Pharmaceutical } \\
\text { preparation }\end{array}$ & Composition & Company \\
\hline Ceftriaxone sodium vial & $\begin{array}{c}\text { Per vial } \\
\text { g Ceftriaxone sodium }\end{array}$ & $\begin{array}{c}\text { Sanaita,PharmaceuticalG } \\
\text { MBH company } \\
\text { (Werne Germany) }\end{array}$ \\
\hline $\begin{array}{c}\text { Ceftriaxone sodium } \\
\text { Vial(Philtriaxone) }\end{array}$ & $\begin{array}{c}\text { Per vial } \\
\text { Binh duong company, } \\
\text { Vietnam }\end{array}$ \\
\hline $\begin{array}{c}\text { Ceftriaxone sodium } \\
\text { Vial(Rameceftrix) }\end{array}$ & $\begin{array}{c}\text { Per vial } \\
\text { Ceftriaxone sodium }\end{array}$ & $\begin{array}{c}\text { Tenth of Ramadan for } \\
\text { pharm.industries } \\
\text { company (Egypt) }\end{array}$ \\
\hline $\begin{array}{c}\text { Ceftriaxone sodium } \\
\text { Vial(Roth) }\end{array}$ & $\begin{array}{c}\text { Per vial } \\
\text { Pharma Roth Gmbh } \\
\text { company (Germany) }\end{array}$ \\
\hline $\begin{array}{c}\text { Ceftriaxone sodium } \\
\text { Vial(Enoxirt) }\end{array}$ & $\begin{array}{c}\text { Per vial } \\
\text { Gulf Pharmaceutical } \\
\text { industries (UAE) }\end{array}$ \\
\hline
\end{tabular}

Table 2. Pharmaceutical preparation studied for Ceftazidime sodium

\begin{tabular}{|c|c|c|}
\hline $\begin{array}{c}\text { Pharmaceutical } \\
\text { preparation }\end{array}$ & Composition & Company \\
\hline Ceftazidime I.M-I.V & $\begin{array}{c}\text { Per vial } \\
\text { 1g Ceftazidime pentahydrate }\end{array}$ & $\begin{array}{c}\text { Laboratorios Torlan Ctra } \\
\text { (Barcelona Spain ) }\end{array}$ \\
\hline Negacef Ceftazidime I.V. & $\begin{array}{c}\text { Per vial } \\
\text { Gulf Pharmacutical } \\
\text { Industries (U.A.E) }\end{array}$ \\
\hline Ceftazidime Roth IV/IM & Peftazidime pentahydrate & $\begin{array}{c}\text { Pharma Roth Gmbh } \\
\text { (Wiesbaden Germany) }\end{array}$ \\
\hline
\end{tabular}

Table 3. Analytical Data for the time fixed procedure of the kinetic spectrophotometric procedures for investigation of ceft and cfz drugs

\begin{tabular}{|c|c|c|}
\hline Parameter & Value with (ceft) & Value with (cfz) \\
\hline$\lambda \mathrm{max}, \mathrm{nm}$ & 426 & 412 \\
\hline Correlation coefficient $\mathrm{r}^{2}$ & 0.9992 & 0,9989 \\
\hline Slope(a) & 0.0301 & 0.0226 \\
\hline $\begin{array}{c}\text { The Molar absorptivity }\left(\mathrm{L} . \mathrm{mol}^{-}\right. \\
\left.\text {.cm }^{-1}\right)\end{array}$ & $1.9926 \times 10^{4}$ & $1.4396 \times 10^{4}$ \\
\hline The law of Beer limits $(\mu \mathrm{g} / \mathrm{ml})$ & $(4-60)$ & $(5-50)$ \\
\hline $\begin{array}{c}\text { the sensitivity of Sandell }\left(\mu \mathrm{g} . \mathrm{cm}^{-}\right. \\
2)\end{array}$ & $4.5 \times 10^{-5}$ & $3.5 \times 10^{-5}$ \\
\hline Intercept $(\mathrm{b})^{-5}$ & 0.0344 & 0.0052 \\
\hline $\begin{array}{c}\text { The detection Limit }(\mathrm{LOD}) \\
\left(\mu \mathrm{g} \cdot \mathrm{ml}^{-1}\right)\end{array}$ & 1.121 & 1.883 \\
\hline $\begin{array}{c}\text { The quantification Limit }(\mathrm{LOQ}) \\
\left(\mu \mathrm{g} . \mathrm{ml}^{-1}\right)\end{array}$ & 1.943 & 2.421 \\
\hline Average recovery & $\% 100.42$ & $\% 99.92$ \\
\hline RSD $^{\text {RSD }}$ & $\% 1.26$ & $\% 1.51$ \\
\hline
\end{tabular}


Table 4. Excipients eEffect at $200 \mathrm{ppm}$ on the recovery of ceft and cfz drugs at $20 \mathrm{ppm}$ for the fixed time method

\begin{tabular}{|c|c|c|c|c|}
\hline Interference & $\begin{array}{c}\text { \% Error } \\
\text { With (ceft) }\end{array}$ & $\begin{array}{c}\text { \% Recovery } \\
\text { With (ceft) }\end{array}$ & $\begin{array}{c}\text { \% Error } \\
\text { With (cfz) }\end{array}$ & $\begin{array}{c}\text { \% Recovery } \\
\text { With (cfz) }\end{array}$ \\
\hline Talc & -1.180 & 98.820 & -0.991 & 99.009 \\
\hline lactose & +1.140 & 101.140 & -1.021 & 98.979 \\
\hline Acacia & +1.030 & 101.030 & -0.772 & 99.228 \\
\hline Starch & -1.640 & 98.360 & -0.551 & 99.449 \\
\hline Glucose & -1.300 & 98.700 & -1.101 & 98.899 \\
\hline Sucrose & +1.150 & 101.150 & -1.411 & 98.589 \\
\hline magnesium stearate & -1.600 & 98.400 & -1.521 & 98.479 \\
\hline Aspartate & +1.010 & 101.010 & -0.821 & 99.179 \\
\hline PVP & +1.450 & 101.450 & -0.765 & 99.235 \\
\hline
\end{tabular}

Table 5. Spectrophotometric attributes of the colored products in different organic solvents

\begin{tabular}{|c|c|c|c|c|}
\hline Solvent & $\lambda_{\max }, \mathrm{nm}($ ceft $)$ & $\lambda_{\max }, \mathrm{nm}(\mathrm{cfz})$ & $\begin{array}{l}\varepsilon, \mathrm{L} \cdot \mathrm{mol}^{-1} \text {. } \\
\mathrm{cm}^{-1} \text { (ceft) }\end{array}$ & $\begin{array}{l}\varepsilon, \mathrm{L} \cdot \mathrm{mol}^{-1} \\
. \mathrm{cm}^{-1}(\mathrm{cfz})\end{array}$ \\
\hline Acetone & 378 & 372 & $1.146 \times 10^{3}$ & $1.228 \times 10^{3}$ \\
\hline Chloroform & 402 & 380 & $1.3368 \times 10^{3}$ & $2.425 \times 10^{2}$ \\
\hline 2- propanol & 368 & 376 & $4.321 \times 10^{2}$ & $1.721 \times 10^{3}$ \\
\hline Acetic acid & 346 & 350 & $1.871 \times 10^{2}$ & $1.278 \times 10^{2}$ \\
\hline Dimethyl sulphoxide & 370 & 368 & $2.262 \times 10^{2}$ & $1.410 \times 10^{3}$ \\
\hline $\mathrm{CCl}_{4}$ & 380 & 372 & $1.005 \times 10^{3}$ & $1.201 \times 10^{2}$ \\
\hline Dioxine & 382 & 390 & $1.412 \times 10^{3}$ & $1.211 \times 10^{2}$ \\
\hline Dimethyl formamide & 402 & 350 & $1.510 \times 10^{3}$ & $1.612 \times 10^{3}$ \\
\hline Ethanol & 426 & 412 & $1.667 \times 10^{4}$ & $1.233 \times 10^{4}$ \\
\hline Benzene & 330 & 340 & $2.301 \times 10^{2}$ & $1.308 \times 10^{2}$ \\
\hline Methanol & 408 & 402 & $1.252 \times 10^{4}$ & $1.161 \times 10^{4}$ \\
\hline Teri butyl alcohol & 406 & 394 & $1.138 \times 10^{4}$ & $1.020 \times 10^{4}$ \\
\hline Formic acid & 390 & 386 & $2.961 \times 10^{2}$ & $1.712 \times 10^{3}$ \\
\hline Pyridine & 360 & 362 & $1.213 \times 10^{3}$ & $1.420 \times 10^{3}$ \\
\hline Di ethyl ether & 372 & 366 & $1.712 \times 10^{2}$ & $1.310 \times 10^{3}$ \\
\hline
\end{tabular}

Table 6. The recovery $\%$ and average RSD $\%$ of ceft drug pure and pharmaceutic forms

\begin{tabular}{|c|c|c|c|c|}
\hline \multirow{2}{*}{$\begin{array}{c}\text { Pharmaceutical preparations including } \\
\text { ceft }\end{array}$} & \multicolumn{3}{|c|}{\begin{tabular}{c} 
Average recovery \% and average RSD\% \\
\cline { 2 - 5 }
\end{tabular}} & \multicolumn{2}{c|}{$\begin{array}{c}\text { Proposed } \\
\text { procedure }\end{array}$} & \multicolumn{2}{c|}{$\begin{array}{c}\text { Standard } \\
\text { procedure }\end{array}$} \\
\hline Pure ceft & 100.42 & 1.26 & 100.88 & 1.41 \\
\hline Ceftriaxone sodium Vial (1g)Germany) ceft & 101.16 & 1.33 & 99.13 & 1.11 \\
\hline $\begin{array}{c}\text { Ceftriaxone sodium (1g) Vietnam } \\
\text { Vial(Philtriaxone)ceft }\end{array}$ & 99.31 & 1.87 & 100.47 & 0.89 \\
\hline $\begin{array}{c}\text { Ceftriaxone sodium (1g)Eygpt } \\
\text { Vial(Rameceftrix) ) ceft }\end{array}$ & 100.22 & 1.57 & 100.12 & 1.65 \\
\hline $\begin{array}{c}\text { Ceftriaxone sodium(1g) )ceft Germany } \\
\text { Vial(Roth) }\end{array}$ & 99.77 & 0.89 & 99.54 & 1.07 \\
\hline $\begin{array}{c}\text { Ceftriaxone sodium (1g) U.A.E } \\
\text { Vial(Enoxirt) ) ceft }\end{array}$ & 100.4 & 0.78 & 100.32 & 1.31 \\
\hline
\end{tabular}


Table 7. The recovery $\%$ and average RSD $\%$ of cfz drug pure and pharmaceutic forms

\begin{tabular}{|c|c|c|c|c|}
\hline \multirow{2}{*}{$\begin{array}{c}\text { Pharmaceutical preparations including } \\
\text { cfz }\end{array}$} & \multicolumn{3}{|c|}{\begin{tabular}{c} 
Average recovery \% and average RSD\% \\
\cline { 2 - 5 }
\end{tabular}} & \multicolumn{2}{|c|}{$\begin{array}{c}\text { Proposed } \\
\text { procedure }\end{array}$} & \multicolumn{2}{c|}{$\begin{array}{c}\text { Standard } \\
\text { procedure }\end{array}$} \\
\hline Pure cfz & 99.92 & 1.51 & 99.33 & 0.91 \\
\hline Ceftazidime I.M-I.V(1g)Spain cfz & 99.56 & 1.22 & 99.51 & 1.03 \\
\hline Negacef Ceftazidime I.V.(1g)U.A.E cfz & 99.12 & 0.82 & 99.17 & 1.46 \\
\hline Ceftazidime RothIV/IM(1g)Germany cfz & 98.88 & 1.12 & 99.23 & 0.96 \\
\hline
\end{tabular}<smiles>CO/N=C(\C(=O)NC1C(=O)N2C(C(=O)O)=C(CSc3nc(=O)c(=O)[nH]n3C)CS[C@H]12)c1csc(N)n1</smiles>

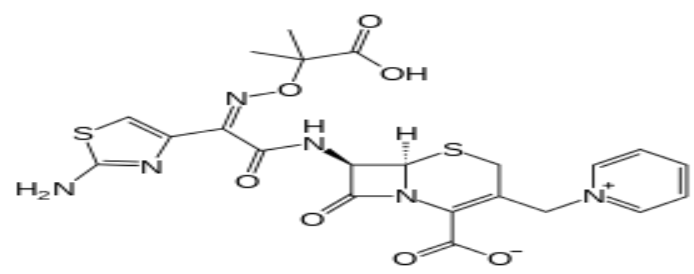

Figure 1. The chemical structures of (Ceftriaxone as well as Ceftazidime ) antibiotics

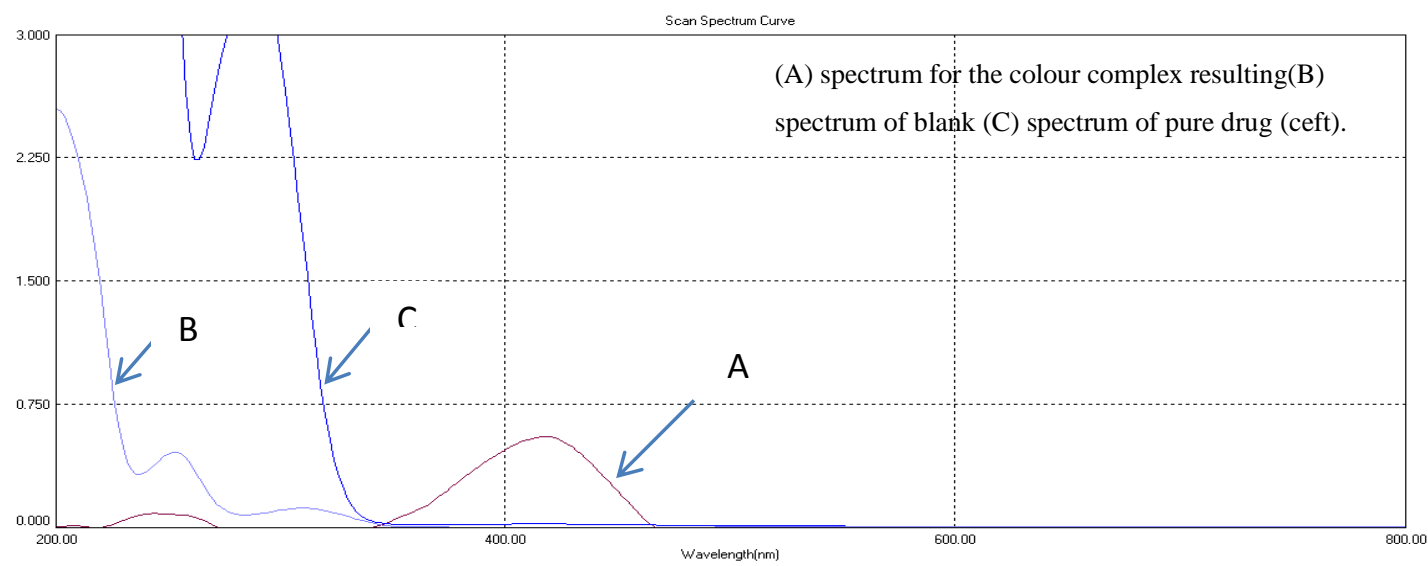

Figure 2. Appears the spectra of the color complex made by the reaction between the ceft drug $1 \mathrm{ml}$ of $500 \mathrm{ppm}$ and reagent against blank solution, the absorption was maximum at 426 $\mathrm{nm}$ where (A) spectrum gives the color for complex resulting by the reaction, (B) is obtaining the spectrum of the blank $2 \mathrm{ml}$ of $0.04 \mathrm{M}$ reagent, (C) spectrum represents the spectrum for the pure drug ceft 


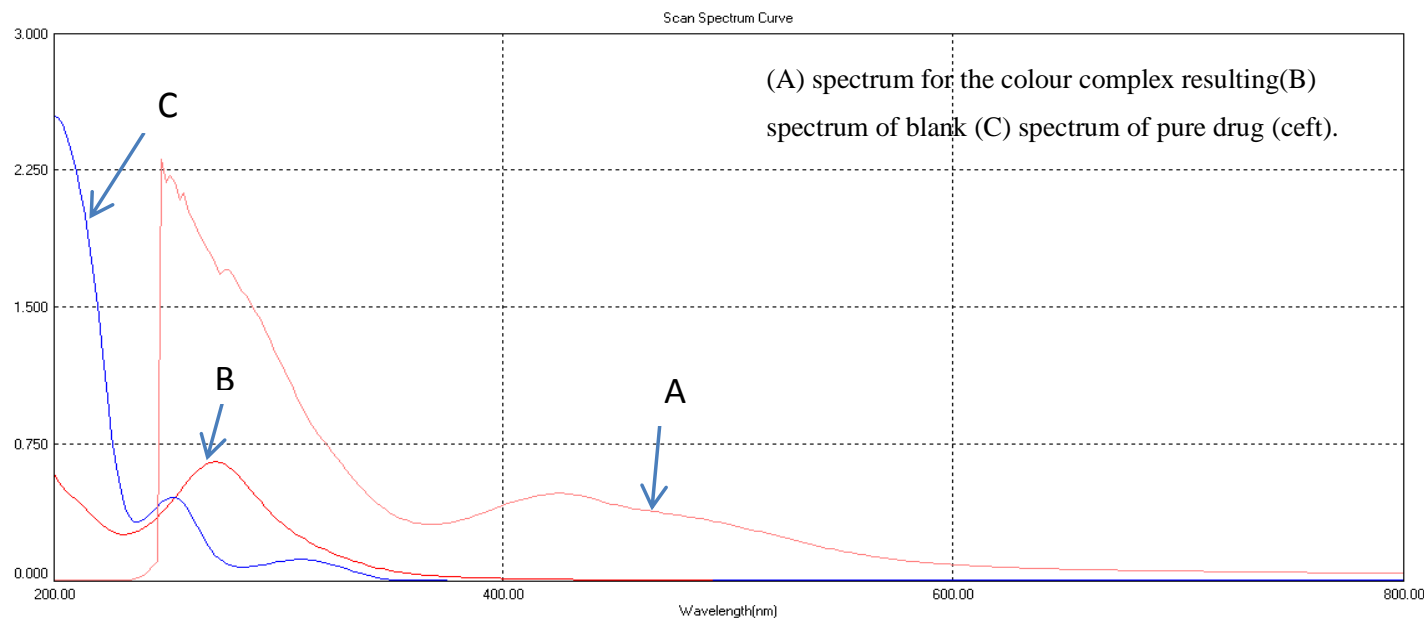

Figure 3. The spectra of the color complex formed by the reaction between the cfz drug $1 \mathrm{ml}$ of $500 \mathrm{ppm}$ and reagent against blank solution, the absorption was maximum at $412 \mathrm{~nm}$ where (A) spectrum gives the color for complex resulting by the reaction, (B) is obtaining the spectrum of the blank $2 \mathrm{ml}$ of $0.04 \mathrm{M}$ reagent, (C) spectrum represents the spectrum for the pure drug cfz

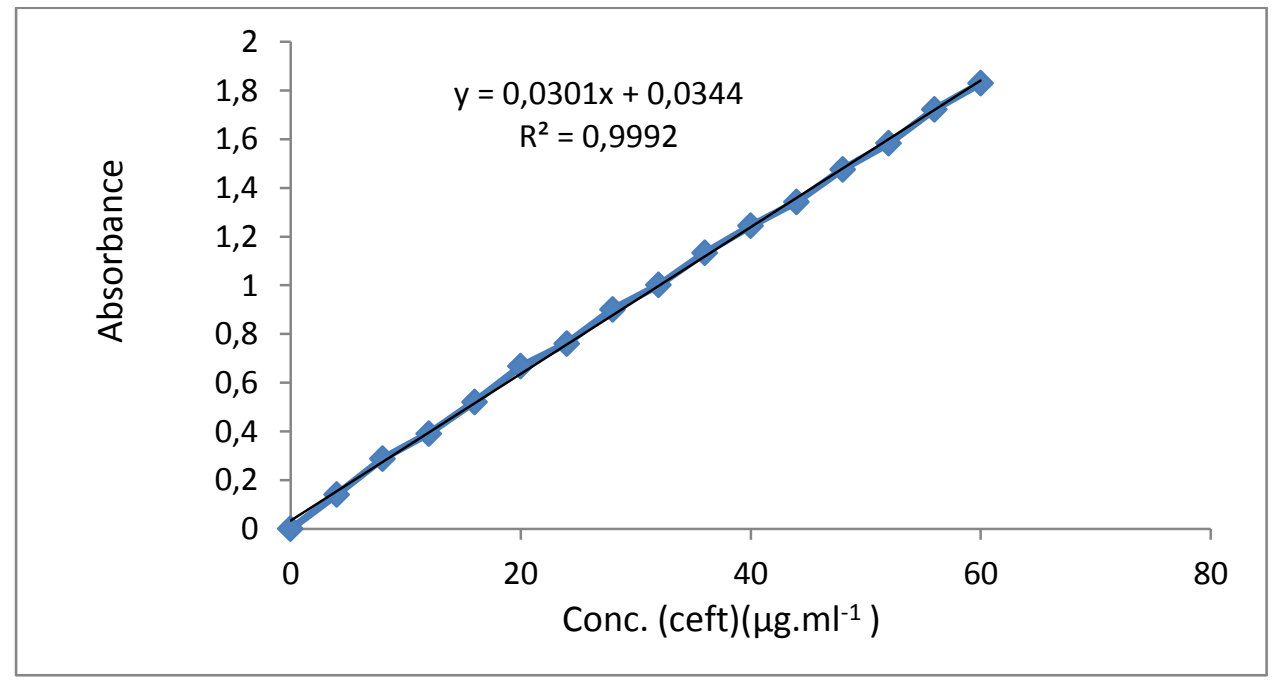

Figure 4. The Calibration curve of ceft 


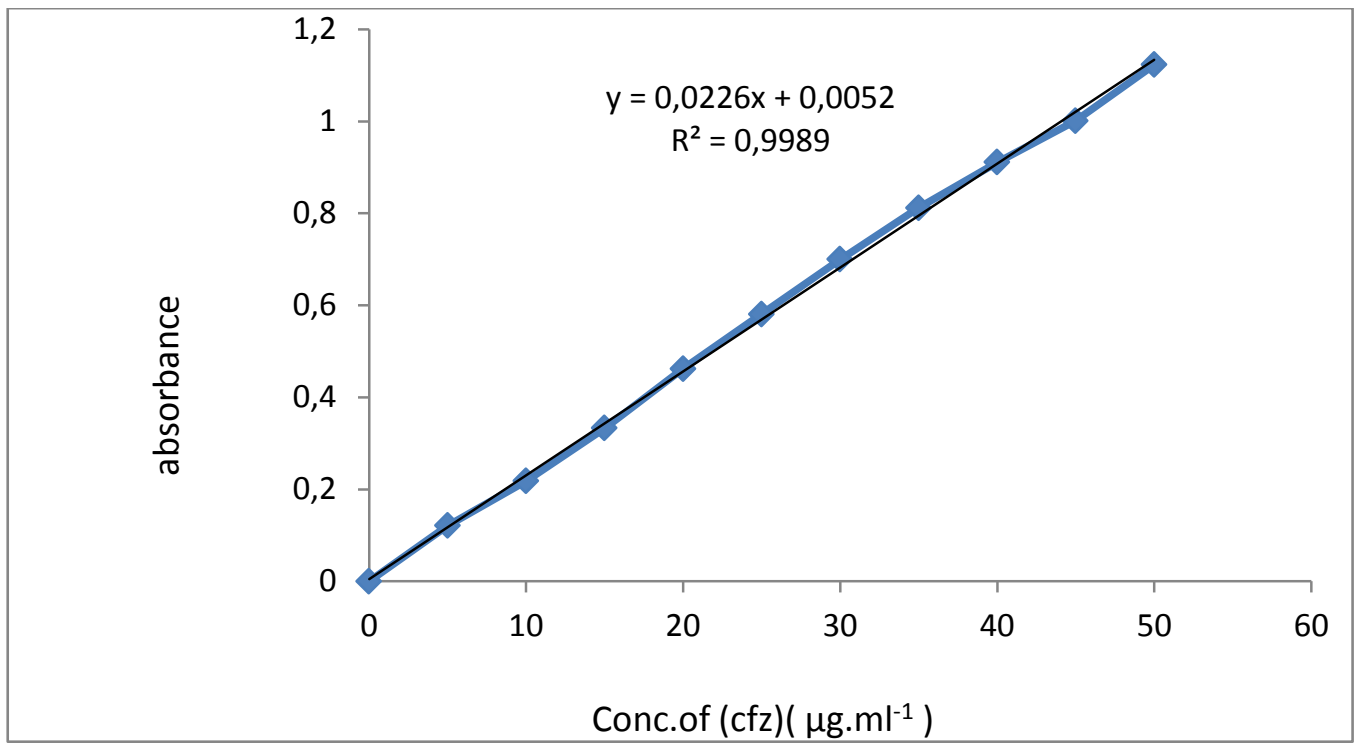

Fig 5. The Calibration curve of cfz

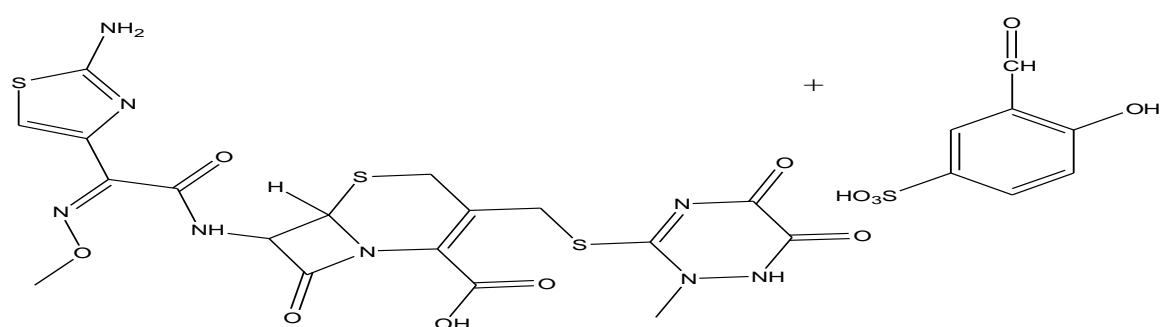

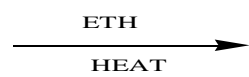<smiles>N=C(S)N=Cc1cc(O)ccc1O</smiles><smiles>[2H]C12SCC(CSc3nc(=O)c(=O)[nH]n3C)=C(C(=O)O)N1C(=O)C2NC(=O)C(=N\OC)/C(N)=C/C</smiles>

Figure 6. Scheme of probable interaction pathway for the figuration of the color product of ceft medicine with 5SSA 


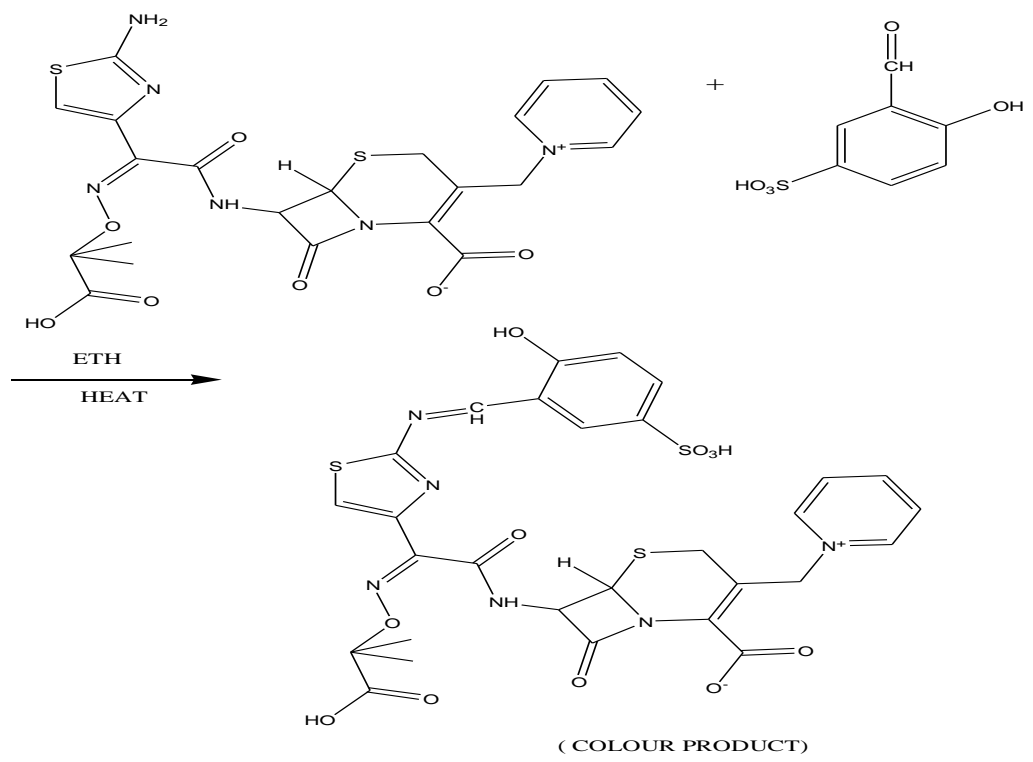

Figure 7. Scheme of probable interaction pathway for the figuration of the color product of cfz medicine with 5SSA 